\title{
Writing News Item in English Language Teaching Context: Line Apps Platform for Senior High School Students
}

\author{
Tia Dwi Risani \\ Universitas Lancang Kuning, Pekanbaru, Indonesia \\ tiadwirisanii@gmail.com
}

\begin{abstract}
Received : 2020-03-05
Revised : 2020-03-18

Accepted :2020-03-25
\end{abstract}

ARTICLE HISTORY

\section{KEYWORDS}

Electronic Devices

Writing News Item

Line App

Descriptive qualitative

\begin{abstract}
Learning English nowadays is a process of giving learners not just skills its also an innovative learning technique, and creative ways are needed as well. The Information Communication Technology (ICT) device such as social media, i.e., Line provides students to explore more in learning English. This research aimed at proving social media such as Line today can be used as virtual support for English language Teaching (ELT) process of writing news item in senior high school. This descriptive qualitative research was conducted on classroom during the subject news item. In this study, the research belongs to the interpretivism paradigm or related to the explaining or understanding the meaning of a sentence or passage. The result of this research is using a virtual or electronic device not only could help students as a learner but the essential things in learning process namely teachers also need virtual to support teaching process and even virtual assessment help teachers and even students to develop learning process especially by using Line apps for writing news item.
\end{abstract}

\section{Introduction}

Teaching is a process to share knowledge among teachers as facilitator and students. Also teaching is a system of actions intended to produce learning by B.O (Smith, 1960). Another definition defined by Edmund (Amidon, 1967) that teaching as an interactive process, primarily involving classroom talk which takes place among teachers and learners during certain definable activities. It is a process in which learner, teacher, curriculum and other variables are organized is a systematic and psychological way to attain some predetermined goals. Another definition explains that Teaching is human engineering and soul doctoring. Teaching refers to the multiple tasks carried out by the teacher for leading the learners to the expected learning. In now era, as the teachers, we should provide the right media to support learning system. So, the media could be influences the students" motivation during the process of learning.

Virtual technology such as social media devices is one of the right tools to support or helping teachers when teaching students. And this one matches with conditions right now that we called millennial or 4.0 era. Many ways to support teachers when teaching students by using virtual software or apps (Aswad, M., Rahman, F., Said, I. M., Hamuddin, B., \& Nurchalis, N. F., 2019), some applications easy to download to support the learning process, one of some familiar application that can support the learning system is Line Today. This one is originally part of the biggest chatting apps, namely line. The line is a freeware app for instant communications on electronic devices such as smartphones, tablet computers, and personal computers. The line also supports texts, images, video and audio, and conduct a free conversation and video conferences. The line is an application that works on multiple platforms and has access via multiple personal computers. The application provides the message, stickers, games, line friends, line pay, line taxi, line wow, lineman and the last but not lease to easy catching the information whole world with line today. This one is a news hub integrates into the line app. Line was initially developed as a mobile application for Android and IOS smartphones. This app really familiar with students and often used to communicate with each other.

Furthermore, not only focus on something relate with communication also line support the system to makes everyone out there easy to catch the information about the world. The line today is the part of the line that presents some information such as English news, showbiz, sport, life, channel, and movie and so on. As the name, common line shares newest information comes from the whole world. Based on illustrating above, this application can help the teacher to teach in the class, especially when the teacher wants to teach subject about kind of type of text, like a news item. 
Based on the Oxford English Dictionary, the news item is a text which informs readers about events of the day. This text related to the news, there are two kinds of news item text, written and spoken. News that we read on newspapers is written text form and news that we hear on radio or television is spoken text form. The events are considered newsworthy or important. It means if there is an important event that should be known by many people, then this event deserves news. Well, the news texts are called the news item text. However, if there are events that people do not earn, then they are not worthy of being news.

A news item text is ordered systematically. The generic structure of the news item is different from another type of texts. News item text has its structure. News item text consists of newsworthy event, background events, and sources by Eltis (1990). In the process of learning, many students encountered problems in writing a news item text. First, the students are lack of knowledge or view of news item text. Second, the students are lack of ideas, information. In other to help students to write a news item, the teacher can apply an electronic device or application like line today, Electronic devices are usually small. They can be grouped into packages called integrated circuits. This miniaturization is central to the modern electronics boom. One of the tools from the line today, namely English Section will help students to get a lot of information about the world (news), with this one can support the student to develop their knowledge about news update. With the English section on Line today, the teachers also can directly teach the student about happening news, and no need to take a long time to get the news. Because the news automatically changes every day.

Moreover, based on the 4.0 era teacher should provide some tools to help the student in the learning process, with learn news item by line today as well as makes students mastered using IT-based on education 21 century. This one focus on how to stimulate the student to learn by using virtual assessment based on authentic tools that they are usually used as a habit. During the process of teaching news item by using line today, the teacher should control the students on how to be the wise people on using the internet. There are a lot of advantages if we are as the teacher use virtually as the tools to help the learning process.

\section{Literature Review}

Teaching involves setting appropriate learning expectations for students, and for that purpose, includes selection and sequencing of activities or kinds of interactions that would lead to expected learning. As teachers we tend to think that teaching is all about teachers and our rule; in fact, the most important aspects of the educational process are the students, and what they learn, during teach student as a teacher we have to aware about the concept of teaching, there are two concepts of teaching; the traditional concept is the act of imparting instructions to the learners in the classroom situation. The teacher gives information to the students, or one of the students reads from the text-book, while the other students silently follow him in their textbooks. And the other one is a modern concept; to cause the student to learn and acquire the desired knowledge, skills, and also desirable ways of living in society. It is a process in which learner, teacher, curriculum and other variables are organized is a systematic and psychological way to attain some pre-determined goals.

Another definition explains that Teaching is human engineering and soul doctoring. Teaching refers to the multiple tasks carried out by the teacher for leading the learners to the expected learning. In the words of English (1959) "the teaching is the art of assisting others to learn. It includes the providing of information (instruction) and of appropriate situation, conditions or activities design to facilitate learning." Teaching is an arrangement and manipulation of a situation in which there are gaps and obstructions which an individual will seek to overcome and from which he will learn in the course of doing so by John Brubacher (1939).

Moreover, Lawrence (1966) defines teaching as a complicated process to be studied entirely in a "live" situation. In other words, teaching is a series of events where the teacher attempts to change the behaviour of the students in the intended direction. Another expert Gage (1963) claimed in his book " Handbook of research on teaching " tried to give a concise account of information on teaching which at places is so incomplete and diverse that no conclusion can be drawn for the nature of teaching (Nofita, N. S. G., Yudar, R. S., \& Nursafira, M. S., 2019).

On the other hand, Morse and Wingo (1968); Susilo, N. (2019). viewed the teaching as understanding and guiding of students as individual and as groups. It means the providing of learning experiences that will enable each learner to grow continuously and sequentially towards a role in society. To support teacher during the teaching process, there is an electronic device or virtual. , Murphy and RodríguezManzanares (2008) found that to decrease the students' sense of transactional distance, teachers needed to build rapport and community with their students. But they also found that the curriculum and teacher-centred tools (such as the learning management system) placed limitations on online teachers and that teachers needed to leverage their real-time interaction and engagement with students. 
Electronic devices are components for controlling the flow of electrical currents for information processing and system control. Prominent examples include transistors and diodes. Electronic devices are usually small and can be grouped into packages called integrated circuits. This miniaturization is central to the modern electronics boom. The identification of the electron in 1897, along with the invention of the vacuum tube, which could amplify and rectify small electrical signals. As of 2018 most electronic devices use semiconductor components to perform electron control. Based on the explanation clearly about an electronic device, the line is one of million application support by the electronic device.

The line is an application that works on multiple platforms and has access via multiple personal computers. The application provides the message, stickers, games, line friends, line pay, line taxi, line wow, lineman and the last but not lease to easy catching the information whole world with line today. This one is a news hub integrates into the line app. Teaching news item by line today will help students to get more knowledge about news especially. The news item is part of the type of text known as part of writing skills. Writing is an essential skill that must be mastered by students in learning English. According to Bryne (1983), he defines that writing is more than the production of the graphic symbols; writing requires a conscious effort in which one can put ideas. Another expert claimed that there are two kinds of writing activities. The first one is writing as a process in which students focus more on various classroom activities. Next is writing as a product, students are engaged in imitating, copying, and transforming the model of correct language.

A news item text is ordered systematically. The generic structure of the news item is different from another type of texts. News item text has its structure. News item text consists of newsworthy event, background events, and sources by Eltis (1990). In the process of learning, many students encountered problems in writing a news item text. First, the students are lack of knowledge or view of news item text. Second, the students are lack of ideas, and information News item consists of newsworthy events, background events and sources by Eltis (1990). Furthermore, Hedge (2002) mention that was writing as a thinking process and a process of discovery. One of the genres which are learned by the students in writing is news item text. Gerot and Wignell (1994) mention news item is a text which is grouped into the text genre of narration. It is a text which contains about news is categorized as a news item. Therefore, it needs a fact that should fulfil specific criteria based on the types of news. Moreover, a news item is a text ordered systematically.

\section{Method}

This research is done by using descriptive qualitative research. Qualitative research is the research that enables the researcher to conduct in-depth studies about a broad array topic, including everyday terms. (Yin, 2011: 6). It means that qualitative research is the study about a broad array topic and describing social phenomena as they occurred naturally, involves studying the meaning of people's lives, under realworld conditions, qualitative research takes place in the natural setting.

The study is conducted on classroom during the subject news item. In this study, the research belongs to the interpretivism paradigm (related to the explaining or understanding the meaning of a sentence or passage), because it is designed to be consistent with the assumption of the qualitative study. In this case, qualitative research is defined to understand a particular social or human problem. According to Creswell (2009), he mentions that "qualitative observations are those which the researcher takes field notes on the situation, behaviour, interaction and activities of individuals at the research site".

\section{Findings}

Following this activity, learning is a process of giving learners to have the ability or skills in learning English. It requires an innovative learning technique and creative so that learners have the competence to English, especially writing skill. Virtual or electric devices is one of the right tools to support or helping teachers when teaching the students. And this one matches with conditions right now. That we called millennial or 4.0 era. Many ways to support teachers when teaching students by using virtual, some applications easy to download to support the learning process, one of some familiar application that can support the learning system is Line Today. I doused Line Today as virtual to support learning system when teaching subject news item in Senior High School.

Line Today present one of the tools that can make students know well about the lesson and even they can be mastered about it. That tool, namely the English section, this one provide some news comes from the whole world belong Indonesian. Certainly, the English section as virtual will help and support the learning process. As we know, for now on all the students using the internet connection to communicate with each other or to know anything about the world. So, this virtual not hard to find out, and based on the survey; line as the application has been downloaded by all Indonesian belongs to me. So that's why I decide to the used line as the virtual to teach my students in senior high school level. 
The implications of using electronic devices to teach students in subject writing a news item as follow: a good teacher is a well-prepared teacher. Good preparation is needed to have the teaching and learning process run well. As the teacher, we should have some preparations before bringing the lesson to the class. In teaching a writing news item text by virtual, the preparation is related to the teaching material, media and exercise which are accommodated in the lesson plan. Here the teacher plays the role as facilitator.

While news item activity, students can easily give more examples of the news item. Also with there is line today as virtual, especially on the English section, it can help students to find out the update news, what happening right now. So with this virtual, can also help the student to know what happens around their automatically increase their knowledge about something. If we go back with the way teacher teach their students only used handbook, I can imagine that students just know about news item with a general statement, like definitions, generic structure, and one example of the news item that usually used every semester and there is no upgrading. In this condition, students just follow what the teachers are talking about, but if using virtual, we help students to mind the gap.

Moreover, during the process of teaching news item by using line today, the teacher should control the students how to be the wise people on using the internet, there are a lot of advantages if we are as the teacher use virtually as the tools to help learning process. Still, also there is a negative effect will we deserve if we cannot control the students to use that application. Give them treatment or illustration during the process of learning by using virtual. Besides, using line today, especially the English section, the help we are as the teacher to applying the rule of new curriculum about students' centre. With using this application, they try to find out the subject and can show off the example based on their effort.

\section{Conclusion}

Base on the previous discussion, it can be concluded that Electronic devices are components for controlling the flow of electrical currents for information processing and system control. Prominent examples include transistors and diodes. Electronic devices are usually small and can be grouped into packages called integrated circuits. This miniaturization is central to the modern electronics boom. Virtual assessment as the tool help students during the learning process. The line today is one of a million application can help students during the process learn about the subject news item. Also, this electronic device support students to be self-sufficient as long as they learn about the news item. English section online today provide information come from the whole world, and the news updates every day. So with this virtual, can also help the student to know what happens around their automatically increase their knowledge about something. Using virtual or electronic device not only could help students as a learner but the important things in the learning process, namely teachers also need virtual to support the teaching process. The last but not lease using line today, especially the English section, the help we are as the teacher to applying the rule of new curriculum about students centre. With using this application, they try to find out the subject and can show off the example based on their effort. Media virtual as one of million way to support teacher make better learning process specifically not only for a news item, it also can apply to other subject.

Then, to have this activity runs well, therefore this study suggests for future researcher to looking for another virtual assessment that suitable for Senior High School in all aspect learning and also should be able to encourage the students to be active and fully involved in this activity.

\section{References}

Aswad, M., Rahman, F., Said, I. M., Hamuddin, B., \& Nurchalis, N. F. (2019). A Software to Increase English Learning Outcomes: An Acceleration Model of English as the Second Language. The Asian EFL Journal. 26. (6.2), 157-169.

Barbour, M. K. (2013). The landscape of K-12 online learning: Examining what is known. In M. G. Moore (Ed.), Handbook of distance education (3rd ed., pp. 574-593). New York: Routledge.

Bose, B. K., \& Bose, B. K. (Eds.). (1997). Power electronics and variable frequency drives: technology and applications (Vol. 996). Piscataway, NJ: IEEE press.

Brubacher, J. S. (1969). Modern Philosophies of Education, 1939. Student edition, MacGrawhill, 21.

Bryne, Donn. (1983). Teaching Writing Skill. London: Four, Strong, Printing Company.

Chang, M. S., \& Chang, C. Y. (2019). LINE Messenger Forensics on Windows 10. Journal of Computers, 30(1), 114-125.

Eltis, K. J., 1990. A Genre-based Approach to Teaching Writing Book 3: Factual Writing. Australia: Common Ground. Gerot.

Floyd, T. L., \& Buchla, D. (2009). Electronics fundamentals: circuits, devices \& applications. Prentice Hall Press. 
Gage, N.L. (Ed) (1963). Handbook of research on teaching: Rand McNally : Chicago.

Guarneri, M. (2012) "The age of vacuum tubes: Early devices and the rise of radio communication. "

Guarneri, M. (2012) "The age of vacuum tubes: Merging with Digital Computing “

Guarneri, M. (2012) "The age of vacuum tubes: the conquest of analog communications."

Hedge, Tricia. (2002). Teaching and Learning in the Language Classroom. London: Oxford University Press.

Hedge, Tricia. (2002). Writing. London: Oxford University Press.

Linda and Peter Wighell. (1994). Making Sense of Functional Grammar: An Introductory. Workbook. Australia

Morris, S. (2002). Teaching and learning online: A stepby-step guide for designing an online K-12 school program. Lanham, MD: Scarecrow Press Inc.

Murphy, E. (2009). Online synchronous communication in the second-language classroom. Canadian Journal of Learning and Technology, 35(3). Retrieved from http://www.cjlt.ca/index.php/cjlt/article/view/539

Nofita, N. S. G., Yudar, R. S., \& Nursafira, M. S. (2019). Exploring Quantity and Diversity of Informal Digital Learning of English (IDLE): A Review of Selected Paper. Utamax: Journal of Ultimate Research and Trends in Education, 1(1), $1-6$.

Safhira, S., \& Hamuddin, B. (2019). Online Interactive Communication via Academic Blogging Activities among Indonesian EFL Students. REiLA: Journal of Research and Innovation in Language, 1(2), 4654.

Susilo, N. (2019). Kahoot Apps in ELT Context: An alternative Learning Strategy. ELSYA: Journal of English Language Studies, 1(1), 11-15. 